Poznańskie Studia Teologiczne 28(2014), s. 213-230.

doi: $10.14746 /$ pst.2014.28.14

Janusz Kościelniak

Uniwersytet Papieski Jana Pawła II

Kraków

\title{
Socjologiczne czytanie Biblii. Odnalezione dzieło Bóg Chrystus i Ludzie. Studium socjologiczne ks. Franciszka Mirka (1893-1970)
}

\section{Wstęp}

Twórczość ks. Franciszka Mirka koncentrowała się wokół tematów związanych z socjologia, a często była przykładem praktycznego zastosowania metod socjologicznych w badaniu różnych przejawów urzeczywistniania się relacji społecznych. Przykładem tego jest praca Bóg Chrystus i Ludzie. Dzieło to nie zostało opublikowane, co więcej - nie było nawet znane. W czasie prowadzenia badań związanych z przygotowaniem doktoratu o ks. F. Mirku autorowi udało się niniejszą pracę odnaleźć. W archiwum Kurii Metropolitalnej znajduje się pozytywna opinia cenzora kościelnego na jej temat. Dziełu ks. Mirka można przyznać pewne nowatorstwo, autor wykorzystuje bowiem warsztat metod socjologicznych do analizy Biblii. Dla zrozumienia sposobu analizowania przez ks. Mirka tekstu biblijnego istotne jest uświadomienie sobie, że był on przedstawicielem socjologii humanistycznej i jej metodami się posługiwał. Główną przesłanką przedstawicieli socjologii humanistycznej jest odrzucenie tezy o monizmie metodologicznym nauk. Nauki o społeczeństwie są zasadniczo inne od przyrodniczych i wymagają odmiennych metod badania. Przedstawicielami socjologii humanistycznej byli: Max Weber, Ferdinand Tönnies, Georg Simmel, Florian Znaniecki, którego uczniem był ks. Franciszek Mirek, Stanisław Ossowski. Poza Polską jest ona określana jako socjologia rozumiejąca. Socjologia humanistyczna stosuje rozumienie jako swą główną procedurę badawczą. Stefan Nowak w następujący sposób definiował rozumienie:

Nawiązując do terminologicznych propozycji Maksa Webera i faktycznych analiz rozumiejących, występujących w potocznej praktyce dnia codziennego, proponowałbym, aby rozumieniem nazwać czynność polegającą na przypisaniu ludziom, znajdującym się w określonej sytuacji, zachowującym się w określony sposób, bądź też reagującym na pewne bodźce (lub trwalsze sytuacje), stanów psychicznych w sposób istotny powiązany z tymi sytuacjami, zachowaniami, czy reakcjami, przy założeniu, 
że zarówno te stany jak i reakcje między nimi a bodźcami są spostrzegane przez działających tak, jak to odzwierciedla nasz konstrukt ${ }^{1}$.

Rozumienie w socjologii humanistycznej określane jest również mianem współczynnika humanistycznego. Autorem tego terminu jest Florian Znaniecki, który wywarł znaczny wpływ na drogę naukową ks. Franciszka Mirka. Z badaniami z uwzględnieniem współczynnika humanistycznego związana jest określona procedura: analiza i interpretacja tzw. dokumentów osobistych, czyli zapisów dokonanych spontanicznie przez działające jednostki, są to m.in.: listy, pamiętniki, wspomnienia. Można przyjąć, że takimi szczególnymi dokumentami była dla ks. Mirka Biblia.

\section{Prezentacja postaci ks. Franciszka Mirka ${ }^{2}$}

Ksiądz Franciszek Mirek, którego dotyczy artykuł, urodził się 20 czerwca 1893 roku w Naprawie, w rodzinie chłopskiej. Jego rodzinna miejscowość to wioska licząca obecnie niespełna 2000 mieszkańców, należy ona do gminy Jordanów. To tam późniejszy ksiądz ukończył dwie pierwsze klasy szkoły podstawowej, trzecią przebył w Jordanowie, czwartą zaś w Myślenicach. Kolejny etap edukacji ks. Mirka związany jest z Krakowem. Po ukończeniu szkoły podstawowej kontynuował bowiem naukę w Gimnazjum św. Anny - dzisiejszym I Liceum Ogólnokształcącym im. B. Nowodworskiego. To elitarne gimnazjum ks. Mirek ukończył z wyróżnieniem w 1912 roku. Następnie wstapił do Krakowskiego Seminarium Duchownego, jednocześnie rozpoczynając studia na Wydziale Teologicznym Uniwersytetu Jagiellońskiego. Studia te ukończył w 1916 roku, jednak absolutorium uzyskał dopiero 8 stycznia roku 1921. Magisterium z teologii otrzymał zaś dekadę później - w roku 1931 na Uniwersytecie Warszawskim na podstawie pracy Podstawa obowiazku, jako zagadnienie moralne. W Warszawie ks. Mirek studiował teologię przez rok na przestrzeni lat 1929-1930. Nieznane sa przyczyny tak zagmatwanej chronologii zdobywania tytułów naukowych przez księdza. Magisterium z teologii otrzymał wtedy, gdy był już docentem socjolo-

${ }^{1} \mathrm{~S}$. Nowak, Obserwacje i rozumienie ludzkich zachowań a problemy budowy teorii, w: S Nowak, Studia z metodologii nauk społecznych, Warszawa, 1965, s. 221-222.

${ }^{2}$ Dane biograficzne dotyczące ks. Franciszka Mirka zostały oparte na następujących źródłach: Archiwum Kurii Metropolitalnej w Krakowie. Teki personalne: Pers A 1179; W. Wincławski, Stownik biograficzny socjologii polskiej, t. 2, Toruń 2004, s. 331-332; F. Adamski, Ks. Franciszek Mirek: Pionier socjologii parafii, w: K. Sowa (red.), Szkice z historii socjologii polskiej, Warszawa 1983, s. 384-396; M. Gawlik, J. Szczepaniak, Księża katecheci diecezji krakowskiej 1880-1939. Stownik biograficzny, t. 1, Kraków 2000, s. 227; J. Kracik, Mirek Franciszek, w: Stownik polskich teologów katolickich 1918-1981, t. 6, Warszawa 1981, s. 487-488; J. Kościelniak, Pastoralne aspekty koncepcji socjologii parafii ks. Franciszka Mirka (1893-1970), Kraków 2013; D. Malinowski, Franciszka Mirka koncepcja socjologii humanistycznej, Kraków 2005. 
gii, o czym będzie mowa później. Po święceniach kapłańskich rozpoczął pracę duszpasterską. Najpierw pracował w Zakopanem, gdzie został wysłany prawdopodobnie ze względów zdrowotnych. Po urlopie zdrowotnym - od 1 stycznia 1917 roku do 31 lipca 1919 roku - pracował w parafii w Czarnym Dunajcu. Od 1 sierpnia 1919 roku do 15 grudnia 1920 roku pełnił obowiązki wikariusza parafii Ofiarowania NMP w Wadowicach. Następnie został skierowany do parafii św. Anny do Krakowa i przebywał tam od 16 grudnia 1920 roku do 15 kwietna 1921 roku. W 1922 roku skierowano go na dalszą naukę do Strasburga. Studiował tam na Wydziale Prawa i Ekonomii w latach 1922-1924. Owocem studiów prawniczych w Strasburgu jest rozprawa doktorska Le pouvoir législatif dans l'ancienne Pologne: (des origines jusqu'à la première moitié du XVI siècle) (Władza ustawodawcza w dawnej Polsce w okresie pierwszej połowy XVI wieku) wydana w Grenoble w 1924 roku. Ksiądz Mirek otrzymał tytuł doktora praw (Docteur en Droit de l'Université, z wyszczególnieniem Science politiques et economiques). Po powrocie ze studiów od 16 sierpnia 1924 roku rozpoczął pracę jako notariusz w kurii krakowskiej, wykorzystując w praktyce zdobytą wiedzę prawniczą. W 1925 roku ks. Franciszek Mirek za zgodą władz kościelnych rozpoczął studia na Uniwersytecie Poznańskim. W roku akademickim 1925/1926 został słuchaczem wykładów z socjologii, prowadzonych przez Floriana Znanieckiego, który miał duży wpływ na jego późniejszą działalność naukową. Pod kierunkiem Floriana Znanieckiego przygotowywał rozprawę doktorską pod tytułem System socjologiczny Ludwika Gumplowicza. Po obronie doktoratu uczony przygotowywał rozprawę habilitacyjną. W 1930 roku habilitował się jako docent socjologii na podstawie pracy Metoda socjologiczna. Przyczynek na podstawie analizy krytycznej Metod Tarde'a i Durkheima. Po obronie habilitacji ks. Mirek rozpoczął pracę na Uniwersytecie Poznańskim.

Po okresie studiów i wykładów w Poznaniu 1 kwietnia 1931 roku został mianowany administratorem Parafii św. Mikołaja w Krakowie. Pełnił te obowiązki do 21 września 1932 roku. Dnia 15 września 1932 roku ks. Franciszek Mirek został mianowany proboszczem w Nowej Górze. Pracował tam do 1946 roku. Po powrocie do diecezji krakowskiej nie zaprzestał pracy naukowej. Obowiązki proboszcza łączył z wykładami w Szkole Nauk Politycznych przy Wydziale Prawa i Administracji Uniwersytetu Jagiellońskiego. Po wojnie podjął pracę jako profesor kontraktowy na Katolickim Uniwersytecie Lubelskim. Wykładał w latach 1946-1949 na Wydziale Prawa i Nauk Społeczno-Ekonomicznych. Głoszone przez niego poglądy, że nauka nie może być ukierunkowana światopoglądowo, oraz aresztowanie przez władze komunistyczne stały się przeszkodą do prowadzenia przez niego dalszych wykładów z socjologii na lubelskiej uczelni. Dnia 31 stycznia 1946 roku został mianowany administratorem parafii św. Józefa w Krakowie, a później proboszczem. Pomimo iż nie mógł już prowadzić wykładów ani publikować, nie zaprzestał badań naukowych. Prowadził bardzo usyste- 
matyzowany styl życia, jak wspominali jego parafianie, codziennie sześć godzin przeznaczał na pracę naukową. W związku z chorobą ks. Mirek złożył rezygnację ze stanowiska proboszcza 27 maja 1968 roku. Rezygnacja ta została przyjęta przez ówczesnego bp. kard. Karola Wojtyłę. Ksiądz Franciszek Mirek zmarł 16 marca 1970 roku i został pochowany w Łętowni, gdzie do dzisiaj znajduje się jego grób.

Ksiądz Mirek pozostawił bardzo bogaty dorobek piśmienniczy. Jego artykuły i książki związane były z działalnością naukową, ale dotyczyły również spraw duszpasterskich. W swojej twórczości uczony często odwoływał się do Biblii, przykładem tego jest dokonany przez niego przekład psalmów. Takim dziełem jest również rozprawa Bóg Chrystus i Ludzie ${ }^{3}$. Praca ta nie została wydana. Autorowi artykułu udało się odnaleźć maszynopis tego dzieła. Jest to nowatorskie spojrzenie na historię zbawienia z punktu widzenia socjologa. Praca, obok wstępu, w którym mieści się uzasadnienie możliwości socjologicznego ujęcia problemu „Bóg i ludzie”, podzielona została na trzy części. W części I ks. Mirek określił i wyjaśnił cechy stosunku społecznego: „Bóg Chrystus - Ludzie” na tle historycznego przebiegu dziejów objawienia. W II części przedstawił szczegółową analizę stosunku społecznego „Chrystus - Ludzie” w jego rozwoju historycznym. W III części zostały omówione wynikające $\mathrm{z}$ tego stosunku wzajemne obowiązki Boga Chrystusa i ludzi. W całej książce ks. Franciszek Mirek, posługując się warsztatem socjologicznym, dokonuje analizy relacji Bóg - człowiek.

\section{Biblia jako źródło materiałów socjograficznych}

Człowiek jest osobą. To oznacza, że jest zdolny do dialogu, do nawiązywania kontaktów i relacji międzyludzkich. Relacje interpersonalne, czyli związki między ludźmi, to sposób wyrażania interakcji uczuć i postaw między dwoma lub więcej partnerami.

Karl Barth zauważył:

Co to znaczy ,ja"? Wypowiadam to słowo i dokonuję tym samym [...] pewnego rozróżnienia oraz ustanawiam pewną relację. [...] Słowem tym odróżniam siebie od drugiego człowieka, który nie jest mna, ale też nie jest jakimś „to”, jakimś przedmiotem, lecz kimś, kto moje oznajmienie siebie jako ,ja” może przyjść, ocenić i zrozumieć, sam bowiem jest $\mathrm{w}$ stanie $\mathrm{w}$ ten sam sposób oznajmić siebie mnie. Odróżniając siebie od tego drugiego człowieka zakładam, akceptuję i ustanawiam - o ile to ode mnie zależy - również relację względem niego: względem niego jako równego mnie. Zwracając się do tego przedmiotu jako ,ja", odróżniam go przecież nie tylko od siebie, lecz także od wszystkich innych przedmiotów, od wszelkiego „to”, stawiam go ze

\footnotetext{
${ }^{3}$ F. Mirek, Bóg Chrystus i Ludzie. Studium socjologiczne, maszynopis, archiwum autora.
} 
sobą samym $[\ldots] \mathrm{w}$ tej samej przestrzeni, wyznaję, że w swojej przestrzeni nie jestem bez niego, że moja przestrzeń jest nie tylko moja, lecz również jego ${ }^{4}$.

Dialog wyróżnia nas od całego otaczającego nas świata materialnego i zwierzęcego. Szczególną formą dialogu jest relacja zachodząca między Bogiem a człowiekiem. Wykorzystując metody badawcze socjologii, opierając się na Biblii, właśnie temu zagadnieniu ks. Franciszek Mirek poświęcił jedną ze swych niepublikowanych prac.

Jak zauważył ksiądz uczony, każda praca socjologiczna - jeśli nie ma być filozofią lub historiozofią - musi opierać się na konkretnym materiale socjograficznym. We wstępie swojej książki ks. Mirek zadał pytanie: „Czy mamy konkretne materiały do badania wzajemnego stosunku Boga Chrystusa i ludzi z punktu widzenia socjologii?" Jak zauważył, Bóg Chrystus jest prawdziwym człowiekiem. Dla socjologa-katolika jest to pewnik. Dla socjologa, który jest osobą niewierząca, są dostępne dowody świadczące o historyczności osoby Jezusa Chrystusa. Jeśli więc Chrystus jest historycznym człowiekiem, a socjologia zajmuje się stosunkiem człowieka do człowieka pod określonym kątem widzenia, to studium o wzajemnym stosunku Chrystusa i ludzi jest przedmiotem badań zarówno teologa, jak i socjologa. Pojawia się problem w przypadku socjologicznej analizy relacji Bóg Chrystus - Ludzie. Ksiądz Franciszek Mirek twierdził, że taka analiza jest możliwa, ponieważ Chrystus, Bóg człowiek jest wedle nauki Kościoła taką jednością, której w żaden sposób realnie nie można rozdzielić. Jak zauważa dalej, sam Bóg Chrystus twierdzi, że istnieje stosunek pomiędzy Nim a ludźmi. Rzeczywistość jest więc niewątpliwa w świadomości przynajmniej jednego partnera stosunku - Chrystusa. Stwierdzamy jednak taką świadomość również u ludzi. Święty Paweł mówi: „Żyję nie ja, żyje we mnie Chrystus”. Mamy szereg dowodów w Biblii, że sam Bóg, nieskończona, najwyższa wedle teologii i filozofii istota, nawiązuje stosunki z ludźmi. Skoro tak, to i ten stosunek Bóg Człowiek - ludzie może być przedmiotem badań socjologa. Materiałem socjograficznym może być Biblia ${ }^{5}$.

Socjografia to nauka pomocnicza socjologii, zajmuje się opisem społeczeństwa i zachodzących w nim zjawisk. Opiera się ona na zbieraniu dużych ilości materiału empirycznego. Opis socjograficzny ma często charakter eksploracyjny i jest podstawą głębszych i bardziej systematycznych badań socjologicznych, weryfikujących określone hipotezy. Socjografia to opis konkretnego przebiegu społecznego w miejscu i czasie. W takim znaczeniu Biblia może stać się materiałem socjograficznym.

\footnotetext{
${ }^{4}$ Filozofia dialogu, wybrał, opracował i przedmową opatrzył B. Baran, Kraków 1991, s. 135.

${ }^{5}$ F. Mirek, Bóg Chrystus i Ludzie. Studium socjologiczne, dz. cyt. s. 6-9.
} 


\section{Człowiek jako podmiot stosunku społecznego z Bogiem Chrystusem}

Ksiądz Franciszek Mirek, analizując biblijny opis stworzenia człowieka, zauważył, że Bóg już na początku wchodzi z Adamem w przymierze. Jeśli pierwszy człowiek zachowa dane mu przykazanie, będzie żył w raju - „Bo dla nieśmiertelności Bóg stworzył człowieka - uczynił go obrazem swej własnej wieczności. A śmierć weszła na świat przez zawiść diabła i doświadczają jej ci, którzy do niego należą" (Mdr 2,24). Każdy stosunek społeczny wymaga, aby jeden partner rozumiał, a przynajmniej mógł zrozumieć drugiego. Stosunek społeczny zachodzi dopiero wtedy, gdy partnerzy, lub przynajmniej jeden z nich, uświadamiają sobie, że łączy ich lub dzieli jakiś wspólny element, który domaga się spełnienia określonych czynności względem partnera stosunku społecznego. O stosunku społecznym mówić możemy tylko wówczas, kiedy stwierdzamy u podmiotów ze sobą współżyjących pewną świadomą powinność spełnienia lub zaniechania pewnych czynności względem siebie. Tylko te podmioty społeczne - osoby, masy lub grupy społeczne - pozostają względem siebie w stosunkach społecznych, które poczuwają się do obowiązku wypełniania lub zaniechania pewnych czynności w swym wzajemnym współżyciu ${ }^{6}$. Cechą stosunku społecznego jest wielość interakcji, trwałość, normatywna regulacja, wzajemność praw i obowiązków?

Obowiązki płynące z przymierza każą się domyślać, że między Bogiem a Adamem istnieje jakiś łącznik, jakiś środek wzajemnego zrozumienia, gdyby tego nie było, nie byłby to stosunek społeczny, ale jakaś ślepa zależność. Doświadczenie uczy nas, że człowiek może wejść w relację stosunku społecznego tylko z drugim człowiekiem. Nie może być mowy o stosunku społecznym ze światem materialnym czy zwierzęcym. Nasuwa się więc pytanie, jak człowiek istota skończona - nawiązuje stosunek społeczny z Bogiem z Istotą Nieskończoną. Jak zauważył ks. F. Mirek, w tym przypadku potrzebny jest łącznik, który byłby pośrednikiem między Bogiem a człowiekiem ${ }^{8}$.

On jest obrazem Boga niewidzialnego - pierworodnym wobec każdego stworzenia, bo w Nim zostało wszystko stworzone: i to, co w niebiosach, i to, co na ziemi, byty widzialne i niewidzialne, czy Trony, czy Panowania, czy Zwierzchności, czy Władze. Wszystko przez Niego i dla Niego zostało stworzone. On jest przed wszystkim i wszystko w Nim ma istnienie. I On jest Głową Ciała - Kościoła. On jest Początkiem, Pierworodnym spośród umarłych, aby sam zyskał pierwszeństwo we wszystkim. Zechciał bowiem [Bóg], aby w Nim zamieszkała cała Pełnia, i aby przez Niego znów pojednać wszystko z sobą: przez Niego - i to, co na ziemi, i to, co w niebiosach, wprowadziwszy pokój przez krew Jego krzyża. I was, którzy byliście niegdyś

\footnotetext{
${ }^{6}$ Por. F. Mirek, Zarys socjologii, Lublin 1948, s. 456-457.

${ }^{7}$ Por. P. Sztompka, Socjologia, Kraków 2010, s. 89-94.

${ }^{8}$ Por. F. Mirek, Bóg Chrystus i Ludzie. Studium socjologiczne, dz. cyt., s. 69-70.
} 
obcymi [dla Boga] i [Jego] wrogami przez sposób myślenia i wasze złe czyny, teraz znów pojednał w doczesnym Jego ciele przez śmierć, by stawić was wobec siebie jako świętych i nieskalanych, i nienagannych (Kol 1,15-22).

Opierając się na powyższym fragmencie listu św. Pawła, ks. Mirek doszedł do wniosku, że obraz Boży w każdym człowieku to obraz Chrystusa. To on umożliwia Bogu rozmowę, zrozumienie, wzajemne słyszenie się z człowiekiem. Stosunek społeczny między Bogiem a ludźmi może więc być zawiązany przez Jezusa Chrystusa. Jak podkreślił: „człowiek z którym Bóg zawarł pierwszy w historii stosunek społeczny - to nie Adam, ani Ewa, ale Jezus Chrystus w Adamie i Ewie, w Noem, w Abrahamie, Jezus Bóg Syn, druga Osoba Boga, która miała w czasie ludzkim za własną naturę syna człowieczego, a w oczach Boga już ją miała"9. Jak zauważył ks. Mirek, obraz Boży w każdym człowieku to obraz Chrystusa - „I dlatego dzieje świata są chrystocentryczne. Od Boga Chrystusa się zaczynają i na Bogu Chrystusie się kończą. Jam jest Alfa i Omega. Ale nie są przez to zamknięte w Chrystusie, ale poddane są wraz z Chrystusem"10.

Mówiąc o stosunku społecznym między Bogiem a ludźmi, ks. Mirek poddał analizie problem rozmowy człowieka z Bogiem. Wyjaśniał, że mamy z nią do czynienia tylko wówczas, gdy człowiek posługuje się słowami sensownymi, a więc łączącymi materię, dźwięk, drgania strun głosowych i wibracje powietrza z duchem, intelektem, z sensem, ze znaczeniem, z czymś niematerialnym. Nie może zaistnieć społeczny fakt rozmowy, jeśli słowa czy zdania wypowiadane przez jednostkę nie są zrozumiałe przez drugą osobę. Słowo, mowa, zdanie wtedy jest zrozumiałe, gdy wypowiada coś, co jest proste i doświadczalne, gdy to proste i doświadczalne jest wypowiadane w słowach postrzeganych przez ogół ludzi jako sensowne, znaczeniowe, będące własnością wspólną danej grupy społecznej. Wyjaśniając kwestię rozmowy człowieka z Bogiem, odniósł się do Prologu z Ewangelii św. Jana. Słowo, o którym mówi Jan Ewangelista, to Bóg Chrystus. Bóg więc rozmawia z człowiekiem przez Jezusa Chrystusa, który łączy w sobie w sposób nierozerwalny człowieczeństwo z Bóstwem ${ }^{11}$. Bóg rozmawia z ludźmi, a ludzie z Bogiem przez pośrednictwo Jezusa Chrystusa. Uczony podaje na to dowody, które przedstawione są poniżej. Przez cały bieg dziejów Izraela Żydzi przemawiają do Niego, jakby był prawdziwym człowiekiem. Obraz Boga w umysłach Izraelitów nie ulegał jakiejś ewolucyjnej sublimacji, ale trwał do czasów Chrystusa. Żydzi chociaż wierzyli, że Bóg jest Duchem, rozmawiali z Nim, jak zwykło się rozmawiać z kimś, kto ma taką samą naturę jak człowiek, oprócz skłonności do grzechu. W Starym Testamencie zakazane było czynienie jakiejkolwiek podobizny Boga prawdziwego z jakiegokolwiek materiału na jakikol-

\footnotetext{
${ }^{9}$ Tamże, s. 71.

${ }^{10}$ Tamże, s. 71a.

${ }^{11}$ Por. tamże, s. 104-105.
} 
wiek wzór. Nie było jednak zakazane, a nawet było pośrednio nakazane, aby ludzie wyobrażali sobie Boga jako mającego cechy ludzkie. Antropomorfizmy i antropopatyzmy powszechnie występują w Biblii. Szczególnie istotne są te wyobrażenia, które występują w psalmach. Jako przykłady ks. Franciszek Mirek przytacza fragmenty niektórych psalmów m.in. ${ }^{12}$ :

Ps. 2 - Śmieje się Ten, który mieszka w niebie,

Pan się z nich naigrawa,

Ps. 18 - Zatrzęsła się i zadrżała ziemia, posady gór się poruszyły,

zatrzęsły się, bo On zapłonął gniewem.

Uniósł się dym z Jego nozdrzy,

a z Jego ust - pochłaniający ogień:

od niego zapaliły się węgle.

Nagiął On niebiosa i zstapił,

a czarna chmura była pod Jego stopami.

Lecąc cwałował na cherubie,

a skrzydła wiatru Go niosły.

Przywdział mrok niby zasłonę wokół siebie,

jako okrycie ciemną wodę, gęste chmury.

Od blasku Jego obecności

rozżarzyły się węgle ogniste.

Pan odezwał się z nieba grzmotem,

to głos swój dał słyszeć Najwyższy,

Ps. 46 - Bóg króluje nad narodami,

Bóg zasiada na swym świętym tronie.

Ps. 90 - Zaiste, Twój gniew nas niszczy,

trwoży nas Twe oburzenie.

Stawiasz przed sobą nasze winy,

nasze skryte grzechy w świetle Twojego oblicza.

Ps. 93 - Pan króluje, oblókł się w majestat,

Pan przywdział potęgę i nią się przepasał:

tak utwierdził świat, że się nie zachwieje.

Ps. 121 - Oto nie zdrzemnie się

ani nie zaśnie

Ten, który czuwa nad Izraelem.

Jak zauważył ks. Franciszek Mirek, na podstawie tych przykładów można stwierdzić, że ludzie mają przekonanie, iż między nimi a Bogiem jest jakieś zasadnicze pokrewieństwo. On, Bóg uczestniczy w ich naturze, a oni - ludzie - w Jego. Pozostaje pytanie, kto jest pośrednikiem między nieskończonym Bogiem a ograniczonym człowiekiem. Jak podkreślił ks. Mirek, jest nim Wcielone Słowo Jezus

\footnotetext{
${ }^{12}$ Tamże, s. 107-110.
} 
Chrystus. Ludzie zaś nie mają bezpośredniego stosunku z Bogiem jako nieskończonym Duchem, dane jest im to dopiero przez człowieczeństwo Jezusa ${ }^{13}$.

Rozpatrując z punktu widzenia socjologii relację Bóg - człowiek, należy zauważyć, że istotnym problemem jest miejsce spotkania Boga z ludźmi. Socjologia miejsce spotkania zalicza do grupy narzędzi styczności społecznej. Ksiądz Mirek pod pojęciem narzędzi styczności społecznej rozumiał zjawisko pośrednictwa między dwoma lub więcej istotami ludzkimi, by mogły się wzajemnie i świadomie zetknąć ze sobą ${ }^{14}$. Stosownie do rodzajów narzędzi rozróżniał te określane przez niego jako tw a r z ą $\mathrm{w}$ twa $\mathrm{r} z$, bezpośrednie oraz wtórne, jeśli dwa podmioty stykają się ze sobą za pomocą np. listu, pisma, wspólnego domu, terytorium itp. Ksiądz Mirek wymieniał następujące typy narzędzi styczności społecznej:

1. Ekumeny. Dla zaktualizowania styczności społecznej jednostki z druga konieczne jest posiadanie przez nią wiedzy o tym, gdzie się znajduje druga osoba. Miejsce pobytu, czyli ekumena, jest narzędziem styczności jednej jednostki z druga. Nie można wejść w bezpośredni kontakt społeczny z drugim człowiekiem, jeśli wpierw nie wie się o jego miejscu zamieszkania.

2. Terytorium. Tak, jak mieszkanie - ekumena - jest lokalizacją przestrzenną jednostki lub jednostek, a przez to narzędziem ich styczności społecznych, tak terytorium jest przede wszystkim umiejscowieniem grupy w przestrzeni; jest ono odpowiedzią na pytanie, gdzie dana grupa się znajduje, gdzie mogę nawiązać z nią styczność społeczna.

3. Wędrówki. Do istoty każdego człowieka należy zmiana, której on podlega. Zmiana ta, czyli ruch, może być ilościowa, np. dziecko rośnie, jakościowa, np. zmiana w poglądach, i przestrzenna (stąd - dotąd). Przedmiotem socjologii są zmiany, jakie na skutek ruchu jednego partnera zachodzą w ruchu drugiego partnera, oraz wzajemne oddziaływanie na siebie tych zmian. Ksiądz Mirek określał wędrówkę jako ruch przestrzenny stąd - dotąd odbywany przez ludzi.

4. Ciało ludzkie jako narzędzie styczności i tożsamości społecznej. Socjologia, badając współżycie ludzi, nie może pominąc ciała ludzkiego. Interesuje się ona jednak ciałem $\mathrm{w}$ przeciwieństwie do innych nauk $\mathrm{z}$ dwu punktów widzenia; ciało jako świadome narzędzie, a raczej zbiór narzędzi styczności z innymi ludźmi oraz ciało jako trwająca podstawa tożsamości osoby w życiu społecznym. Ksiądz Mirek, rozpatrując kwestie ciała jako narzędzia styczności społecznej, objął refleksją tematy takie, jak: spotkanie, wygląd, rozpoznanie, rola społeczna, ubiór ${ }^{15}$.

\footnotetext{
${ }^{13}$ Por. F. Mirek, Bóg Chrystus i Ludzie. Studium socjologiczne, dz. cyt. s. 107-111.

${ }^{14}$ Por. tenże, Zarys socjologii, dz. cyt., s. 94-97.

${ }^{15}$ Tamże, s. 134-176.
} 
Narzędziem styczności społecznej jest miejsce spotkania. Pierwszym miejscem wymienianym przez Biblię, w którym na ziemi ludzie spotykają się z Bogiem, jest raj. Trudno stwierdzić, czy Adam i Ewa widzieli Boga oczami cielesnymi. Biblia nic o tym nie mówi. Mowa jest tylko o głosie Bożym. Można wnioskować, że Adam swoim rozumem poznał istnienie Boga poprzez oglądanie rzeczy, które widział wokół siebie, a ze szczęścia, które odczuwał, oraz z łaskawych słów Boga, które słyszał, mógł wnioskować, że Bóg jest im Ojcem, a oni Jego dziećmi. Raj to nie tylko materialne miejsce, ale i wewnętrzny stan duszy. Stan duszy pierwszych rodziców zmienił się, kiedy przekroczyli łatwe do zachowania przykazanie. I ta zmiana stanu wewnętrznego spowodowała, że raj zamienił się w obecną, wszystkim znaną ziemię, „która rodzi osty”"16.

Kolejnym miejscem spotkania Boga z człowiekiem była Ziemia Obiecana. Izraelici wracają do niej po niewoli egipskiej. Jak zauważył ks. Franciszek Mirek, Bóg uczył Izraelitów nawiązywania z Nim kontaktu przez znaki i czynności w ciagu 40 lat wędrowania po pustyni Synaj. Przede wszystkim Izraelici zostali wyodrębnieni, a nawet odcięci od wszelkiej pomocy ze strony świata. W Egipcie mogli jeszcze liczyć na jakieś znajomości, stosunki, na własne doświadczenie, na prawo państwowe. Na pustyni zostali tego pozbawieni. Została im tylko wiara w słowo Boga głoszone przez Mojżesza ${ }^{17}$. Bóg dawał liczne i nadzwyczajne znaki, których celem było umocnienie słów Mojżesza: grzmoty, pioruny, błyskawice, wodę ze skały, ratunek przed jadem węźów, przepiórki, mannę czy wreszcie przybytek, w którym znajdowała się Arka Przymierza. Bóg posłużył się nimi, aby widzialnie zaznaczyć swoją obecność i łaskę. Przybytek i Arka Przymierza przygotowywały Izraelitów do wybudowania świątyni w Ziemi Obiecanej. Dokonało się to za czasów króla Salomona ${ }^{18}$. Aby zrozumieć znaczenie miejsca spotkania jako narzędzia styczności społecznej, warto przywołać przykład każdego kościoła, którego świątynia izraelska była zapowiedzią, a w którym Bóg jest obecny nie tylko za pomocą znaków, lecz w sposób żywy pod postacią chleba i wina. Według ks. Mirka istotna jest stabilizacja miejsca kultu. Jak zauważył:

Styczność społeczna między kapłanem a wiernymi byłaby niezmiernie utrudniona, gdyby np. miejsce odprawiania liturgii zmieniało się zbyt często, gdyby miejsce pobytu kapłana nie było wszystkim znane. Podobne zachodziłyby trudności, gdyby miejsce spotkań religijnych grupy parafialnej mogło być przez kogoś obcego, np. inną grupę religijną lub państwową dowolnie zajmowane i administrowane ${ }^{19}$.

Kościół ma wielkie znaczenie dla grupy parafialnej, ponieważ przechowuje się w nim postaci eucharystyczne. Ksiądz Mirek sformułował następujące twierdzenie:

\footnotetext{
${ }^{16}$ Por. F. Mirek, Bóg Chrystus i Ludzie. Studium socjologiczne, dz. cyt., s. 115-118.

${ }^{17}$ Por. tamże, s. 119-122.

${ }^{18}$ Por. tamże, s. 136-146

${ }^{19}$ Por. F. Mirek, Elementy społeczne parafii rzymskokatolickiej, Wstęp do socjologii parafii, Poznań 1928, s. 194.
} 
$\mathrm{Na}$ tej podstawie jest kościół dla wiernych nie tylko zwykłym budynkiem, ale Domem Bożym. Katolik wierzy, że w kościele może on aktualizować swoje prawa i obowiązki, nie tylko jako członek, a więc np. brać udział we wspólnej ofierze, modłach i przyjmować sakramenty św., ale że tutaj jest dla niego miejsce, gdzie może on oddawać cześć Bogu żywemu, Jezusowi Chrystusowi, którego obecność jest localiter zdeterminowana postaciami chleba ${ }^{20}$.

\section{Szczytowa forma relacji Boga $z$ czlowiekiem $w$ tajemnicy wcielenia Syna Bożego}

Tajemnicę wcielenia ks. Mirek rozpatrywał w kontekście akomodacji. Uczony określał ją jako:

Czasowe i zewnętrzne przyswojenie sobie pewnego sposobu wyrażania myśli lub działania partnera społecznego, na którego chcemy lub musimy w jakiś sposób oddziałać, bez zamiaru jednak, aby to przyswojenie obcych celów, dóbr, pragnień miało być stałe i wykluczało nasze osobiste cele i pragnienia [...]. Podmiotem najwięcej uzdolnionym do akomodacji społecznej jest taka osoba, czy grupa, w której świadomość odrębnej osobowości wyrobiła się na podstawie dóbr wewnętrznych, ideowych - dóbr, które pragnie na innych rozszerzyć. Tak osoba lub grupa, zachowuje siebie we wszelkich sytuacjach społecznych, jak długo jej podstawa ideowa jest nienaruszona - pragnienie zaś lub przymus rozszerzenia tych dóbr na innych czynią zdolną do wszelkiej akomodacji, jak długo ta nie zostaje w sprzeczności z jej własną ideologią ${ }^{21}$.

Jak zauważył, niektórzy autorzy posługują się terminem a d a p ta c ja, zamiast a komodacja. Jednak przez adaptację rozumiemy przystosowanie się tak czasowe, jak i trwałe. Na oznaczenie zaś przystosowania trwałego mamy termin asymilacja. Dlatego postulował, aby nie stosować terminu adaptacja na określenie zjawisk związanych $\mathrm{z}$ akomodacją $a^{22}$.

Akomodacja zachodzi wówczas, kiedy zaistnieją trzy elementy:

1. Kultura i cywilizacja, tzn. ogół dóbr i narzędzi styczności partnerów społecznych są tak różne, że nawiązanie i utrzymanie jakiegoś stosunku społecznego lub przynajmniej styczności jest niemożliwe albo bardzo utrudnione.

2. Przynajmniej jeden z partnerów chce lub musi dany stosunek społeczny czy styczność nawiązać lub podtrzymać. Jak zauważył ks. Mirek, najdoskonalszym przykładem akomodacji jest przystosowanie Syna Bożego do natury ludzkiej. „On, istniejąc w postaci Bożej, nie skorzystał ze sposobności, aby na równi być z Bogiem, lecz ogołocił samego siebie, przyjąw-

\footnotetext{
${ }^{20}$ Tamże, s. 195.

${ }^{21}$ F. Mirek, Zarys socjologii, dz. cyt., s. 377-380.

${ }^{22}$ Por. tamże, s. 380.
} 
szy postać sługi, stawszy się podobnym do ludzi. A w zewnętrznym przejawie, uznany za człowieka, uniżył samego siebie, stawszy się posłusznym aż do śmierci - i to śmierci krzyżowej” (Flp 2,6-8).

3. Partner, który chce lub musi dany stosunek nawiązać lub podtrzymać, nie ma innego sposobu, by daną różnicę usunąć, jak akomodacja ${ }^{23}$.

Akomodacja jest dobrowolnym przyswojeniem sobie jakichś właściwości przedmiotu społecznego, o czym przedmiot może początkowo nawet nie wiedzieć. Nie można zaliczyć również do akomodacji zjawiska podporządkowania społecznego. Zjawisko to bowiem zawiera w sobie element władzy, którego w samej akomodacji nie ma.

Akomodacją nie jest również synkretyzm. Przez synkretyzm bowiem rozumiemy pewne połączenie dwu sprzecznych pojęć, sztuczne zacieranie różnic, np. pomiędzy religiami lub systemami filozoficznymi. Synkretyzm określa pewne sztuczne połączenie rzeczy, które z natury swej się wykluczają. W akomodacji zaś takiej sprzeczności nie ma, gdyż idea lub sposób postępowania, które sobie podmiot od przedmiotu przyswaja, są zgodne z ideami i dotychczasowym postępowaniem podmiotu. Innym pojęciem, które czasem według ks. Mirka niesłusznie utożsamia się z akomodacją, jest substytucja. Ma ona miejsce wtedy, gdy dany podmiot społeczny przyswaja sobie od przedmiotu samą tylko formę, a treść pozostawia swoją, albo przyswaja sobie samą treść, a formę pozostawia swoją ${ }^{24}$.

Jak zauważył ks. Mirek, przez Chrystusa, z Chrystusem i w Chrystusie zostali wszyscy ludzie stworzeni na obraz Boży. Bóg, wchodząc w stosunki społeczne z Adamem, wchodzi w stosunek nie z nim, ale także z Chrystusem jako człowiekiem, z Chrystusem, który jako człowiek jest już w Adamie, Abrahamie, Dawidzie.

W tajemnicy wcielenia Bóg nawiązuje szczególny stosunek społeczny z człowiekiem. Relacja między Chrystusem Wcielonym Synem Bożym a ludźmi jest szczytem bliskości między nieskończonym Bogiem i skończonym człowiekiem. Poruszając kwestię stosunku społecznego, ks. Mirek wyciągnął następujące wnioski:

1. Każda grupa społeczna w swoich przedstawicielach wedle swojej kultury osądza daną jednostkę ludzką i ustosunkowuje się do niej.

2. Każda jednostka, pochodząca $\mathrm{z}$ danej grupy społecznej, przesiąka w mniejszym lub większym stopniu poglądami swojej grupy społecznej lub też innych grup społecznych albo nawet innych jednostek.

3. Ludzie oceniają się wzajemnie według takich lub innych norm, obowiązujących w ich obiegu społecznym.

${ }^{23}$ Por. tamże, s. 376; tenże, Elementy społeczne parafii rzymskokatolickiej, dz. cyt., s. 232.

${ }^{24}$ Por. F. Mirek, Elementy spoleczne parafii rzymskokatolickiej, dz. cyt., s. 235-239. 
4. Człowiek wchodzi z innym w stosunki społeczne, które istnieją już przed jego narodzeniem. Jak zauważył ks. Mirek, wśród Żydów istniała powszechna świadomość, że ich zbawicielem będzie Mesjasz. Ta cecha stosunku społecznego nazwana została przez Davida Durkheima, którego dotyczyła rozprawa habilitacyjna ks. Mirka, przymusem społecznym ${ }^{25}$.

Pierwszą osobą na Ziemi, która w sposób najściślejszy, gdyż macierzyński, nawiązała stosunek społeczny z Chrystusem, była Maryja. Scena zwiastowania opisana w Ewangelii św. Łukasza kończy się znamiennymi słowami Maryi: „Oto ja Służebnica Pańska niech mi się stanie według Twego słowa”. Jak zauważył ks. Mirek, Maryja wchodzi tymi słowami w stosunek macierzyński z Jezusem, ale nie bezpośrednio. Fundamentem, ośrodkiem, na którym ten stosunek jest oparty, jest Bóg w Osobie Ojca. Maryja wierzy w Boga, miłuje Go. Ten, który ma się z niej narodzić, jest Synem Bożym. Maryja daje wyraz tej swojej wierze w pieśni Magnificat ${ }^{26}$ : „Wtedy Maryja rzekła: «Wielbi dusza moja Pana, [...] gdyż wielkie rzeczy uczynił mi wszechmocny. Święte jest Jego imię - [...] Ujął się za sługą swoim, Izraelem, pomny na miłosierdzie swoje - jak przyobiecał naszym ojcom - na rzecz Abrahama i jego potomstwa na wieki»" (Łk 1,46$-56)$.

Józef z kolei wchodzi w stosunek społeczny przez Maryję, której jest prawym małżonkiem. Jednak fundamentem, tak małżeństwa Józefa, jak i jego nowego stosunku społecznego, jest Bóg, którego Józef miłuje ${ }^{27}$ -

Mąż Jej, Józef, który był człowiekiem sprawiedliwym i nie chciał narazić Jej na zniesławienie, zamierzał oddalić Ją potajemnie. Gdy powziął tę myśl, oto anioł Pański ukazał mu się we śnie i rzekł: „Józefie, synu Dawida, nie bój się wziąć do siebie Maryi, twej Małżonki; albowiem z Ducha Świętego jest to, co się w Niej poczęło. Porodzi Syna, któremu nadasz imię Jezus, On bowiem zbawi swój lud od jego grzechów". A stało się to wszystko, aby się wypełniło słowo Pańskie powiedziane przez Proroka: Oto Dziewica pocznie i porodzi Syna, któremu nadadzą imię Emmanuel, to znaczy: „Bóg z nami”. Zbudziwszy się ze snu, Józef uczynił tak, jak mu polecił anioł Pański: wziął swoją Małżonkę do siebie, lecz nie zbliżał się do Niej, aż porodziła Syna, któremu nadał imię Jezus. (Mt 1,19-25)

Jan, syn Zachariasza, pozostawał w specjalnym stosunku społecznym z Chrystusem. Już w dzieciństwie dowiedział się, że ma być prorokiem Bożym, głoszącym przyjście Mesjasza - „A i ty, dziecię, prorokiem Najwyższego zwać się będziesz, bo pójdziesz przed Panem torując Mu drogi; Jego ludowi dasz poznać zbawienie [co się dokona] przez odpuszczenie mu grzechów" (Łk 1,77). Kolejni ludzie pozostający w stosunku społecznym z Chrystusem to uczniowie, spośród

\footnotetext{
${ }^{25}$ Por. tenże, Bóg Chrystus i Ludzie. Studium socjologiczne, dz. cyt. s. 150-151.

${ }^{26}$ Por. tamże, s. 190-191.

${ }^{27}$ Por. tamże, s. 192.
} 
których wybrał 12 apostołów. Analizując tekst ks. Mirka dotyczący ludzi nawiązujących stosunek społeczny z Bogiem, można odczuć pewien niedosyt związany $z$ brakiem pogłębionej analizy tych relacji. Uczony w tym przypadku ograniczył się do zrelacjonowania poszczególnych stosunków społecznych.

\section{Wiara jako warunek lączności ludzi z Bogiem Chrystusem}

Jezus pragnie, aby słuchający go ludzie oparli swój stosunek do niego na wierze w Boga, w Boga Ojca. Prawdopodobnie w trzecim roku publicznego nauczania postawiono Jezusowi trudny do rozwiązania problem. Mianowicie, które z 613 przykazań jest najważniejsze dla żydów ${ }^{28}$. I wtedy Jezus odpowiedział:

„Pierwsze jest: Słuchaj, Izraelu, Pan Bóg nasz, Pan jest jeden. Będziesz miłował Pana, Boga swego, całym swoim sercem, całą swoją duszą, całym swoim umysłem i całą swoją mocą. Drugie jest to: Będziesz miłował swego bliźniego jak siebie samego. Nie ma innego przykazania większego od tych”. Rzekł Mu uczony w Piśmie: „Bardzo dobrze, Nauczycielu, słusznieś powiedział, bo Jeden jest i nie ma innego prócz Niego. Miłować Go całym sercem, całym umysłem i całą mocą i miłować bliźniego jak siebie samego daleko więcej znaczy niż wszystkie całopalenia i ofiary" (Mk $12,28-33)^{29}$.

Jeśli na Jezusa z Nazaretu patrzymy przez pryzmat pojęć socjologicznych, stajemy przed zagadką. To, co czyni, jak przemawia, w jaki sposób nawiązuje relacje z ludźmi, nie da się z niczym porównać ani przez wpływ kultury czy środowiska wytłumaczyć. We wszystkich prawie naukach Jezus wraca do tego samego żądania, aby ludzie wierzyli Mu tą samą wiarą, jaką się wierzy tylko Bogu. Ta wiara jest istotnym warunkiem nawiązania łączności z Chrystusem, prawdziwym Bogiem i człowiekiem ${ }^{30}$. Potwierdzają to liczne Jego wypowiedzi: „To bowiem jest wolą Ojca mego, aby każdy, kto widzi Syna i wierzy w Niego, miał życie wieczne. A Ja go wskrzeszę w dniu ostatecznym” (J 6,42); „«Jeśli ktoś jest spragniony, a wierzy we Mnie - niech przyjdzie do Mnie i pije! Jak rzekło Pismo: Strumienie wody żywej popłyną z jego wnętrza». A powiedział to o Duchu, którego mieli otrzymać wierzący w Niego” (J 7,37-38); „Ja jestem zmartwychwstaniem i życiem. Kto we Mnie wierzy, choćby i umarł, żyć będzie. Każdy, kto żyje i wierzy we Mnie, nie umrze na wieki" (J 11,25). W szczególniejszy sposób domaga się wiary od apostołów. Daje temu wyraz w rozmowie pożegnalnej:

\footnotetext{
${ }^{28}$ Por. F. Mirek, Bóg Chrystus i Ludzie. Studium socjologiczne, dz. cyt., s. 193.

${ }^{29}$ Por. tamże, s. 193-195.

${ }^{30}$ Por. tamże, s. 233-236.
} 
Niech się nie trwoży serce wasze. Wierzycie w Boga? I we Mnie wierzcie! [...] Nikt nie przychodzi do Ojca inaczej jak tylko przeze Mnie. Gdybyście Mnie poznali, znalibyście i mojego Ojca. Ale teraz już Go znacie i zobaczyliście”. Rzekł do Niego Filip: „Panie, pokaż nam Ojca, a to nam wystarczy”. Odpowiedział mu Jezus: „Filipie, tak długo jestem z wami, a jeszcze Mnie nie poznałeś? Kto Mnie zobaczył, zobaczył także i Ojca. Dlaczego więc mówisz: «Pokaż nam Ojca?» Czy nie wierzysz, że Ja jestem w Ojcu, a Ojciec we Mnie? Słów tych, które wam mówię, nie wypowiadam od siebie. Ojciec, który trwa we Mnie, On sam dokonuje tych dzieł. Wierzcie $\mathrm{Mi}$, że Ja jestem w Ojcu, a Ojciec we Mnie. Jeżeli zaś nie - wierzcie przynajmniej ze względu na same dzieła!" (J 14,1-11).

Problem wiary ks. Franciszek Mirek poddał socjologicznej analizie. Definiował ją w następujący sposób:

Wiara oznacza pierwotnie prawdziwość albo prawdę. W znaczeniu w jakim używamy tego słowa dzisiaj, nacisk położony jest na podmiotowe uznawanie czegoś za prawdę. Wiara - wierzyć. Uznawać za prawdę. Jeśli wiarę, wierzyć mamy traktować socjologicznie z ogólnego założenia socjologii wynika, że mamy na myśli tę tylko czynność, która odnosi się do słów innego człowieka. W każdym razie możemy łatwo z Ewangelii wywnioskować, że Chrystus, mówiąc o wierze i wierzeniu, rozumie przez to wiarę w to, co on ludziom mówi. On Bóg Człowiek coś mówi, a człowiek jakiś jeden lub więcej uznają za prawdę wszystko to, co On im mówi¹.

Wiara jest to uznanie za prawdę jakichś słów, twierdzeń, tez, nie dlatego, że są one zweryfikowane empirycznie, lecz ze względu na powagę lub miłość do mówiącego. Święty Paweł wyraził to słowami „miłość wszystkiemu wierzy”. W czynności wiary pierwszorzędną rolę odgrywa nie rozum, ale wola. Ksiądz Mirek przytoczył na potwierdzenie tego słowa Soboru Watykańskiego I:

Wiara jest cnotą nadprzyrodzona, przez którą wierzymy, pod wpływem natchnienia i z pomocą łaski Bożej, że prawdą jest to, co Bóg objawił. Wierzymy zaś tak nie z powodu wewnętrznej prawdziwości tych rzeczy, którą moglibyśmy poznać za sprawą naturalnego światła rozumu, ale wierzymy uznając autorytet objawiającego Boga, który nie może się mylić, ani wprowadzać w błąd. Apostoł świadczy, że „,wiara jest poręką tych dóbr, których się spodziewamy, dowodem tej rzeczywistości, której nie widzimy" (Hbr 11,1)

Na podstawie tych tez uczony podał m.in. następujące wnioski:

1. Wiara nie jest i nie może być wiarą wbrew woli człowieka.

2. Wiara jako wybór pochodzący z woli i miłości ludzkiej ma z natury swej tendencję do ujawniania się w czynach zewnętrznych, jak każdy inny akt

${ }^{31}$ F. Mirek, Bóg Chrystus i Ludzie. Studium socjologiczne, dz. cyt., s. 245.

${ }^{32}$ Konstytucja Dei Filius, w: Dokumenty Soborów Powszechnych, t. IV/2: (1511-1870) - Lateran V, Trydent, Watykan I, oprac. A. Baron, H. Pietras, Kraków 2007, s. 29. Por. F. Mirek, Bóg Chrystus i Ludzie. Studium socjologiczne, dz. cyt. s. 251. 
woli i miłości. Brak zewnętrznych oznak wiary jest dowodem braku wiary, a w każdym razie braku silnej wiary.

3. Wiara jako objaw woli jest zawsze czynem etycznym pozytywnie lub negatywnie nacechowanym. Dla katolika wiara w Boga jest czynem etycznym ponad wszystkie inne, gdyż za przedmiot ma samego Boga.

4. W kwestiach wiary większą rolę odgrywają pobudki oddziałujące na wolę niż argumenty rozumowe, jakkolwiek w przygotowaniu do uwierzenia mają one pierwszorzędne znaczenie ${ }^{33}$.

Wiara umożliwia nawiązanie trojakiego stosunku między Bogiem Chrystusem a ludźmi. Mowa o stosunku pasterskim, nauczycielskim i kapłańskim. „Ja Jestem dobrym pasterzem" - mówi o sobie Jezus. Władzę Najwyższego Pasterza obejmuje nie z woli swojej, ale z woli Ojca. Omawiając stosunek wychowawczy, ks. Mirek odniósł się do zagadnienia prawdy. Tę prawdę przynosi Jezus, który sam powiedział: „Poznacie prawdę a prawda was wyzwoli”. Poruszając zagadnienie prawdy, ks. Mirek zauważył, że mamy do czynienia z prawdą subiektywną, podmiotową, w której główną rolę odgrywa nie rozum człowieka, ale jego wola, przypuszczenie i pragnienie. Drugi rodzaj prawdy jest poza człowiekiem. Prawdę tę nazywamy obiektywna, przedmiotową, nieosobową, niezależną od pragnienia i woli ludzkiej. Zbiór faktów, z którymi należy się liczyć, tworzy prawdę obiektywną. Prawda przedmiotowa jest odkrywana pracą rozumu ludzkiego. W poszukiwaniu prawdy obiektywnej ks. Mirek kieruje czytelnika w stronę Biblii. Przytacza fragment Księgi Hioba: „Gdzieś był, gdy zakładałem ziemię? Powiedz, jeżeli znasz mądrość. Kto wybadał jej przestworza? Wiesz, kto ją sznurem wymierzył? Na czym się słupy wspierają? Kto założył jej kamień węgielny ku uciesze porannych gwiazd, ku radości wszystkich synów Bożych?” (Hi 38,4-7). Na podstawie tego fragmentu ks. Mirek doszedł do wniosku, że Bóg tworzy to, co jest, a człowiek to poznaje. Posłannictwem Chrystusa jest dać świadectwo prawdzie ${ }^{34}$.

Rozpatrując stosunek kapłański, ks. Mirek poddał analizie socjologicznej problem ofiary. Jak zauważył, by ofiara była prawdziwa, niezbędne są trzy warunki:

1. Wyraźna - słowem lub gestem zewnętrznym wyrażona wola składającego ofiarę, że to właśnie, co przynosi, ma być ofiarowane Bogu z jego wolnej woli.

2. Kapłan, któremu Bóg udzielił władzy publicznego składania ofiary sobie.

3. Wyraźny znak od Boga, że ofiarę przyjmuje. W Starym Testamencie symbolem tego było spalenie ofiary.

\footnotetext{
${ }^{33}$ Por. F. Mirek, Bóg Chrystus i Ludzie. Studium socjologiczne, dz. cyt., s. 256-257.

${ }^{34}$ Por. tamże, s. 267-272.
} 
Jak zauważa dalej ks. Mirek, Jezus miał wolną wolę. Bóg Ojciec z miłości swej przyjął dobrowolną ofiarę Syna za zbawienie świata. ,,...] Dlatego miłuje Mnie Ojciec, bo Ja życie moje oddaję, aby je [potem] znów odzyskać. Nikt Mi go nie zabiera, lecz Ja od siebie je oddaję. Mam moc je oddać i mam moc je znów odzyskać. Taki nakaz otrzymałem od mojego Ojca»»" (J 10,17)

\title{
Wnioski
}

Stosunek społeczny pomiędzy Bogiem a człowiekiem rozwijał się - jak ukazuje w swojej pracy ks. Mirek - stopniowo. Szczytem jest tu wcielenie Syna Bożego, Jego zbawcza męka i zmartwychwstanie. Racją uzasadniającą analizy socjologiczne jest człowieczeństwo Jezusa Chrystusa i jego historyczność potwierdzona licznymi źródłami. Nowatorskie jest nazwanie przystosowania Syna Bożego do natury ludzkiej w tajemnicy wcielenia najdoskonalszym przykładem akomodacji. W tej tajemnicy Bóg nawiązuje szczególny stosunek społeczny z człowiekiem. Pierwszą osobą, która nawiązuje stosunek społeczny z Chrystusem w sposób najściślejszy, bo macierzyński, była Maryja. Nawiązanie stosunku społecznego między człowiekiem a Bogiem możliwe jest dzięki wierze. Jak podkreśla ks. Mirek, w procesie wiary najważniejszą rolę odgrywa wola człowieka. Praca ks. Franciszka Mirka jest ciekawą próbą spojrzenia na wybrane zagadnienia biblijne okiem socjologa, badającego zjawiska społeczne. Jak wspomniano wcześniej, uczony był przedstawicielem socjologii humanistycznej i jej metodami się posługiwał. Biblia stała się dla niego swoistym przykładem współczynnika humanistycznego, na podstawie którego starał się zrozumieć cechy relacji Bóg - człowiek.

\section{Sociological Reading of the Bible. Recovered Manuscript God Christ and the People. A Sociological Study by Father Franciszek Mirek (1893- -1970)}

\begin{abstract}
This article expounds the rediscovered and unpublished manuscript by Father Franciszek Mirek God Christ and the People. A Sociological Study. Father Franciszek Mirek was the first Polish sociologist who was a member of the group of Florian Zaniecki's students. The recovered manuscript offers an innovative look at the elements of the history of salvation seen through the eyes of a sociologist. The introduction to the paper presents the profile of Father Franciszek Mirek and his most important works. Further parts present the rediscovered manuscript of Fr. Mirek. On its basis the following issues are discussed: the Bible as a source of sociographic data, people as
\end{abstract}

${ }^{35}$ Por. tamże, s. 283. 
partners in relationship with Christ, the apogee of relations between God and a man in the mystery of the Incarnation of the Son of God and faith as a precondition of human communication with God Christ.

\section{Keywords}

Father Franciszek Mirek, sociology, social relation, history of salvation

\section{Slowa kluczowe}

ks. Franciszek Mirek, socjologia, stosunek społeczny, historia zbawienia

\section{Literatura}

Adamski F., Ks. Franciszek Mirek: Pionier socjologii parafii, w: K. Sowa (red.), Szkice z historii socjologii polskiej, PAX, Warszawa 1983, s. 384-396.

Archiwum Kurii Metropolitalnej w Krakowie. Teki personalne: Pers A 1179.

Filozofia dialogu, wybrał, opracował i przedmową opatrzył B. Baran, Wyd. Znak, Kraków 1991.

Gawlik M., Szczepaniak J., Księża Katecheci Diecezji Krakowskiej 1880-1939. Słownik biograficzny, Wydawnictwo św. Stanisława BM, Kraków 2000.

Konstytucja Dei Filius, w: Dokumenty Soborów Powszechnych, t. IV/2: (1511-1870) Lateran V, Trydent, Watykan I, oprac. A. Baron, H. Pietras, Wydawnictwo WAM, Kraków 2007.

Kościelniak J., Pastoralne aspekty koncepcji socjologii parafii ks. Franciszka Mirka (1893-1970), Wydawnictwo Naukowe Uniwersytetu Papieskiego Jana Pawła II w Krakowie, Kraków 2013.

Kracik J., Mirek Franciszek, w: Słownik polskich teologów katolickich 1918-1981, t. 6, ATK, Warszawa 1981, s. 487-488.

Malinowski D., Franciszka Mirka koncepcja socjologii humanistycznej, Zakład Wydawniczy Nomos, Kraków 2005.

Mariański J., Franciszek Mirek, w: M. Libiszowska-Żółtowska, J. Mariański (red.), Leksykon socjologii religii, Verbinum, Warszawa 2004, s. 243.

Mirek F., Bóg Chrystus i Ludzie. Studium socjologiczne, archiwum autora.

Mirek F., Elementy społeczne parafii rzymskokatolickiej. Wstęp do socjologii parafii, Wydawnictwo Fiszer i Majewski, Poznań 1928.

Mirek F., Zarys socjologii, Wydawnictwo KUL, Lublin 1948.

Nowak S., Obserwacja i rozumienie ludzkich zachowań a problemy budowy teorii, w: S. Nowak, Studia z metodologii nauk społecznych, PWN, Warszawa 1965, s. 221-222.

Sztompka P., Socjologia, Wydawnictwo Znak, Kraków 2010.

Wincławski W., Stownik biograficzny socjologii polskiej, t. 2, Wydawnictwo Uniwersytetu Mikołaja Kopernika, Toruń 2004. 